Revista Brasileira de Meteorologia, v.29, n.1, 1 - 12, 2014

\title{
ESTIMATION OF GROSS PRIMARY PRODUCTION OF THE AMAZON-CERRADO TRANSITIONAL FOREST BY REMOTE SENSING TECHNIQUES
}

\author{
MAÍSA CALDAS SOUZA ${ }^{1}$, MARCELO SACARDI BIUDES ${ }^{1}$, \\ VICTOR HUGO DE MORAIS DANELICHEN ${ }^{1}$, NADJA GOMES MACHADO ${ }^{1,2}$, \\ CARLO RALPH DE MUSIS ${ }^{1}$, GEORGE LOUIS VOURLITIS ${ }^{1,3}$ E \\ JOSÉ DE SOUZA NOGUEIRA ${ }^{1}$
}

\author{
${ }^{1}$ Universidade Federal de Mato Grosso (UFMT), Instituto de Física, Cuiabá, MT, Brazil \\ ${ }^{2}$ Instituto Federal de Mato Grosso, Laboratório da Biologia da Conservação, Cuiabá, Mato Grosso, Brazil. \\ ${ }^{3}$ Biological Sciences Department, California State University, San Marcos, California, USA \\ maisacaldas@fisica.ufmt.br, marcelo@fisica.ufmt.br, danelichen@fisica.ufmt.br, \\ nadja.machado@blv.ifmt.edu.br, carlo.ralph@iuni.com.br, georgev@csusm.edu, nogueira@ufmt.br
}

Received December 2012 - Accepted July 2013

\begin{abstract}
The gross primary production (GPP) of ecosystems is an important variable in the study of global climate change. Generally, the GPP has been estimated by micrometeorological techniques. However, these techniques have a high cost of implantation and maintenance, making the use of orbital sensor data an option to be evaluated. Thus, the objective of this study was to evaluate the potential of the MODIS (Moderate Resolution Imaging Spectroradiometer) MOD17A2 product and the vegetation photosynthesis model (VPM) to predict the GPP of the Amazon-Cerrado transitional forest. The GPP predicted by MOD17A2 (GPP $\left.\mathrm{GODIS}_{\mathrm{S}}\right)$ and VPM $\left(\mathrm{GPP}_{\mathrm{VPM}}\right)$ were validated with the GPP estimated by eddy covariance $\left(\mathrm{GPP}_{\mathrm{EC}}\right)$. The GPP $\mathrm{MODIS}_{\mathrm{S}}, \mathrm{GPP}_{\mathrm{VPM}}$ and $\mathrm{GPP}_{\mathrm{EC}}$ have similar seasonality, with higher values in the wet season and lower in the dry season. However, the VPM performed was better than the MOD17A2 to estimate the GPP, due to use local climatic data for predict the light use efficiency, while the MOD17A2 use a global circulation model and the lookup table of each vegetation type to estimate the light use efficiency.
\end{abstract}

Keywords: semi-deciduous forest, VPM model, remote sensing and net $\mathrm{CO}_{2}$ exchange.

RESUMO: ESTIMATIVA DA PRODUTIVIDADE PRIMÁRIA LÍQUIDA BRUTA DA FLORESTA DE TRANSIÇÃO AMAZÔNIA-CERRADO POR TÉCNICAS DE SENSORIAMENTO REMOTO A produtividade primária bruta (GPP) de ecossistemas é uma importante variável no estudo de mudanças climáticas globais. A GPP, geralmente, tem sido estimada por técnicas micrometeorológicas. No entanto, essas técnicas possuem elevado custo de implantação e manutenção, fazendo com que o uso de dados de sensores orbitais seja uma opção a ser avaliada. Sendo assim, o objetivo deste estudo foi avaliar a potencialidade do produto MODIS (Moderate Resolution Imaging Spectroradiometer) MOD17A2 e o modelo de fotossíntese da vegetação (VPM) para estimar a GPP de uma floresta de transição Amazônia-Cerrado. A GPP estimada pelo MOD17A2 (GPP $\mathrm{GODIS}_{\text {) e pelo VPM (GPP }}$ (GPM) foram validadas com a GPP estimada pelo método de correlação de vórtices turbulentos $\left(\mathrm{GPP}_{\mathrm{EC}}\right)$. A GPP ${ }_{\text {MODIS }}, G_{\text {VPM }}$ e GPP ${ }_{\mathrm{EC}}$ apresentaram sazonalidade similar, com maiores valores na estação chuvosa e menores na estação seca. No entanto, o VPM apresentou melhor desempenho do que o MOD17A2 em estimar a GPP, por utilizar dados climáticos locais para estimar a eficiência do uso da luz, enquanto que o produto MODIS utiliza um modelo de circulação global e uma tabela baseada no tipo de vegetação para estimar a eficiência do uso da luz.

Palavras-chave: floresta semidecídua, modelo VPM, sensoriamento remoto e troca líquida de $\mathrm{CO}_{2}$. 


\section{INTRODUCTION}

Tropical forests are important in the control of regional and global climate (Keller et al., 2004; Dalmagro et al., 2011). Brazil has one of the largest expanses of the Amazon forest in the world. According to Bernoux et al. (2002), only the Amazon forest is responsible for $20-25 \%$ of all global carbon storage. Conversion of forests to pasture and crops has altered the carbon cycle in the region, thus it is necessary to understand the impact of anthropogenic activity and climate changes on ecosystem functioning (Vourlitis et al., 2011).

Located $50 \mathrm{~km}$ far from Sinop city, northwest of Mato Grosso State, we feature an Amazon-Cerrado transitional forest. This forest is $423 \mathrm{~m}$ above sea level and is located in a region known as the "arc of deforestation". The forest transition or ecotone, as it is also known, is described as two distinct vegetation that interpenetrate, but each one keeps its own characteristics. Transition forests have a $\mathrm{CO}_{2}$ exchange close to zero due to carbon sink during the wet season and release carbon during the dry season (Vourlitis et al., 2002, 2004). However, this balance can be altered with climate change (Dalmagro et al., 2011).

The study of net ecosystem exchange (NEE) and gross primary production (GPP) provide important information about the environment, as the critical component of the global carbon cycle is the vegetation, mainly due to photosynthesis, which regulates this flux of carbon between the biosphere and atmosphere. The study of carbon flux variation over a time series is very useful to provide the knowledge of possible factors that influence the carbon cycle or even make future estimates (Stagakis et al., 2007). Several methods to measure the carbon flux of a vegetated surface are used. The eddy covariance technique is a key atmospheric measurement technique to measure and calculate the carbon flux within atmospheric boundary layers (Albinet et al., 2012). This technique has been exhaustive used to monitoring the forest carbon exchange (Santos e Costa, 2003; Baldocchi, 2003; Aguiar et al., 2006). However, in some cases, this technique can be impractical because its operating costs and its little representation for heterogeneous locals.

The use of field data integrated with satellite data has become a powerful tool for obtaining information which allow studies of the carbon ecosystem exchange. Studies relying on satellite-based remote sensing indicate that canopy greenness in the Amazon forest is negatively correlated with precipitation patterns with increased greenness and higher productivity occurring during the dry season (Huerte et al., 2006; Myneni et al., 2007). In addition, flux tower measurements indicate that the canopy greening that occurs during the dry season is associated with the net primary production (NPP) and evapotranspiration
(ET) increase during the dry season (Hutyra et al., 2007). This variability pattern is the opposite of observed in several studies and ecosystem model predictions, that overall, seasonal drought causes a decline in productivity (Saleska et al., 2003; Samanta et al., 2010; Zhao and Running, 2010). Such opposite's results highlight the complex interaction between drought, phenology and ecosystem productivity (Saleska et al., 2009).

In this study we combined analyses of satellite images with field data from a $\mathrm{CO}_{2}$ flux tower site of semi-deciduous forest in the Amazon Basin. In general, many current models of ecosystem carbon exchange based on remote sensing require considerable input from ground-based meteorological measurements and lookup tables based on vegetation types (Wu et al., 2010), such as the Moderate Resolution Imaging Spectroradiometer (MODIS) product termed MOD17A2 (Turner et al., 2006; Silva et al., 2013). Recently, the vegetation photosynthesis model (VPM) was developed (Xiao et al., 2004a,b) to predict light absorption by chlorophyll and GPP of terrestrial ecosystems, based on the concept that vegetation canopy is composed of chlorophyll and non-photosynthetically active vegetation. The potential of the VPM for predict GPP has been evaluated by estimates of GPP in flux towers sites in temperate deciduous broadleaf forest (Xiao et al., 2004a,b; Wu et al., 2010), seasonally moist tropical forest (Xiao et al., 2005), and croplands (Li et al., 2007; Wang et al., 2010). However, the VPM has not been evaluated and applied in semi-deciduous forest in the Amazon Basin. Furthermore, these studies have used a fixed light use efficiency to predict GPP. Here, we evaluate the potential of MOD17A2 and VPM to estimate the GPP of the Amazon-Cerrado transitional forest.

\section{MATERIAL AND METHODS}

\subsection{Description of experimental area}

This study was conducted between July 2005 and May 2008, $50 \mathrm{~km}$ from Sinop, Mato Grosso State, Brazil, in the Maracaí Farm. On site, there was a micrometeorological tower of $42 \mathrm{~m}$ height, coordinates $11^{\circ} 24^{\prime} 43.4^{\prime \prime} \mathrm{S}$ and $55^{\circ} 19^{\prime} 25.7^{\prime \prime}$ $\mathrm{W}$, altitude of $435 \mathrm{~m}$ above sea level (Figure 1). The climate is classified as Aw, according to Köppen (Kottek et al., 2006), with a dry season from May to September and a wet season from October to April (Vourlitis et al., 2011). The average annual temperature is $24^{\circ} \mathrm{C}$ and the average annual rainfall is 2037 $\mathrm{mm}$ (Vourlitis et al., 2002). The region is an Amazon-Cerrado transitional forest, defined as tropical semideciduous forest, with trees around $25-28 \mathrm{~m}$ height. The leaf area index (LAI) varies from $5-6 \mathrm{~m}^{2} \mathrm{~m}^{-2}$ in the wet season and $2-2.5 \mathrm{~m}^{2} \mathrm{~m}^{-2}$ in the dry season (Vourlitis et al., 2002; Sanches et al., 2008) and the soil was classified as a sandy soil. 


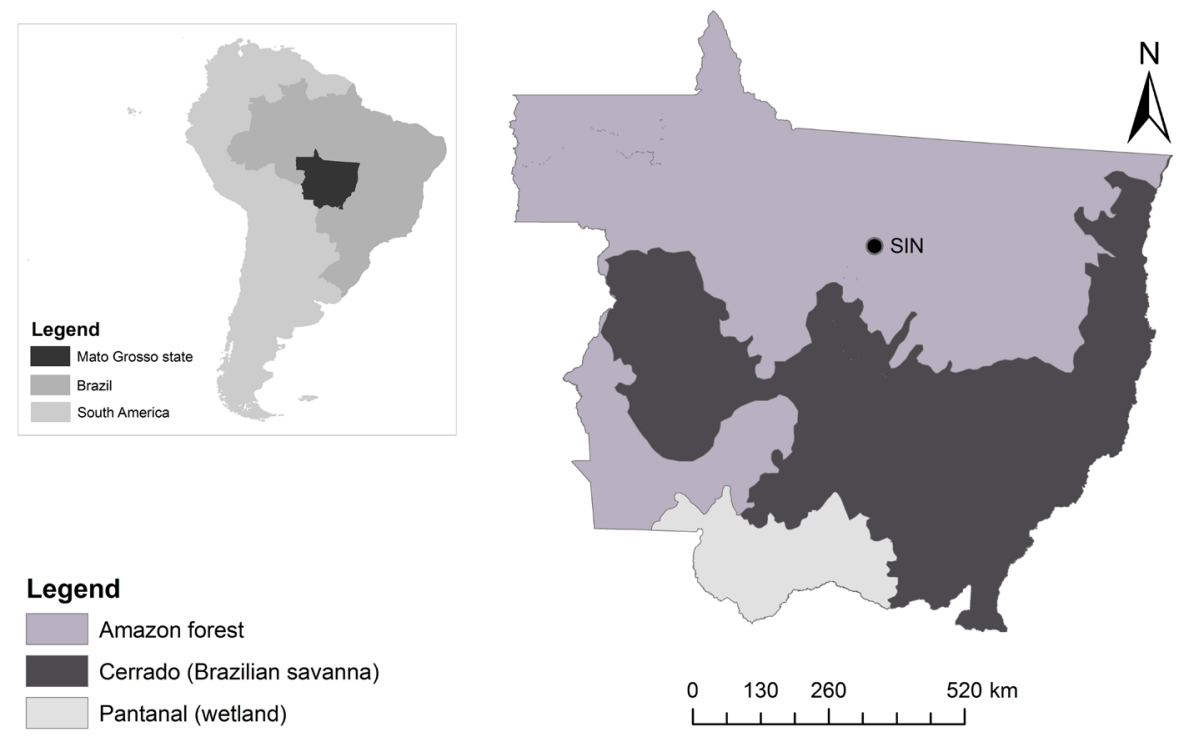

Figure 1 - Location of micrometeorological tower in the Amazon-Cerrado transitional forest.

\subsection{Instrumentation used}

The photosynthetically active radiation was measured using a quantum sensor (LI-190SB, LI-COR, Lincoln, NE, USA) at $40 \mathrm{~m}$ height. The air temperature and relative humidity were measured by a thermohygrometer (HMP-45 C, Vaisala, Inc., Helsinki, Finland) also at $40 \mathrm{~m}$ height. The fluctuation of the three-dimensional wind speed was measured by a sonic anemometer (CSAT-3, Campbell Scientific, Inc., Logan, UT, USA) and the carbon dioxide concentration fluctuating was measured by an infrared gas analyzer (LI-7500, LI-COR, Inc., Lincoln, NE, USA), both installed at $42 \mathrm{~m}$ height. The data signals produced by the transducers were processed at a frequency of $10 \mathrm{~Hz}$ and stored every 30 minutes by a datalogger (CR5000, Campbell Scientific, Inc., Logan, UT, USA). The rainfall was obtained daily in Farm Maracaí by a pluviometer located $5 \mathrm{~km}$ southwest of micrometeorological tower.

\subsection{Eddy covariance method}

The data series used in this study was collected from July 2005 to June 2008. The GPP was measured by the eddy covariance method. This method is most appropriate for studying of physical phenomena in forests because the carbon exchange occurs turbulently (Aguiar, 2006). The infrared gas analyzer was installed at the wind direction approximately $5 \mathrm{~cm}$ of sonic anemometer to minimizing the effect of separation of sensors, and with an inclination of $20^{\circ}$ to prevent water accumulation. The sensors were oriented at the predominant wind direction to minimize estimating distortions. The predominant wind direction was SSW-SW.
The raw data and $\mathrm{CO}_{2}$ flux were stored and processed by a datalogger (CR5000, Campbell Scientific, Inc., Logan, UT, USA). The average $\mathrm{CO}_{2}$ flux was calculated by the covariance between the vertical wind speed fluctuations and $\mathrm{CO}_{2}$ concentration fluctuations. The estimated $\mathrm{CO}_{2}$ flux was corrected by simultaneous heat fluctuation (Webb et al., 1980). The GPP was calculated hourly as the sum of the estimated $\mathrm{CO}_{2}$ flux and the canopy $\mathrm{CO}_{2}$ storage (Grace et al., 1996). The canopy $\mathrm{CO}_{2}$ storage was determined by quantifying the $\mathrm{CO}_{2}$ rate in the air column between the ground and sensors (Vourlitis et al., 2011). The $\mathrm{CO}_{2}$ concentrations were measured using a closed-path infra-red gas analyzer (LI -820, LI-COR, Inc., Lincoln, NE, USA) at 1, 4, 12, 20 and $28 \mathrm{~m}$ above ground level and a diaphragm pump and a solenoid switching system. The estimated GPP $\left(\mathrm{gC} \mathrm{m}^{-2}\right.$ day $\left.^{-1}\right)$ by the eddy covariance method was calculated using the equation:

$$
G P P=N E E+R
$$

where $N E E$ is the net ecosystem exchange $\left(\mathrm{gC} \mathrm{m}^{-2}\right.$ day $\left.^{-1}\right)$ and $\mathrm{R}$ is the ecosystem respiration $\left(\mathrm{gC} \mathrm{m}^{-2}\right.$ day $\left.^{-1}\right)$ (Wohlfarhrt $e t$ $a l ., 2005)$. The GPP and $R$ were calculated half-hourly and integrated for each day. The $R$ of each half-hour was calculated as the average of first four hours of the day of the $N E E$, assuming zero $\mathrm{CO}_{2}$ assimilation during this period (Vourlitis et al., 2011).

\subsection{MODIS 8-day surface reflectance product}

The MODIS is a sensor aboard the Terra and Aqua satellites, acquiring data in 36 spectral bands ranging from 450 $\mathrm{nm}$ to $2100 \mathrm{~nm}$. Of these 36 spectral bands, seven bands of them were designed for the study of vegetation and land surface: 
blue (459-479 nm) - band 3, green (545-565 nm) - band 4, red (620-670 nm) - band 1, near-infrared NIR (841-875 nm, 1230-1250 nm) - band 2 and 5, and short wave infrared SWIR (1628-1652 nm, 2105-2155 nm) - band 6 and 7. The MODIS Land Science Team provides several data products derived from MODIS data, including the 8-day compose Land Surface Reflectance (MOD09A1). The MOD09A1 datasets include seven spectral bands mentioned above, at a spatial resolution of $500 \mathrm{~m}$, corrected for the effects of atmospheric gases, aerosols, and thin cirrus clouds.

We obtained the land surface reflectance data (MOD09A1) based on the geo-location information (latitude and longitude) of eddy covariance flux tower in the AmazonCerrado transitional forest from July 2005 to February 2008. The data are published by the EROS Data Center Active Archive Center (EDC Daac). As noise in vegetation index should be low and the distance between the tower and the edge of the forest is greater than $5 \mathrm{~km}$, we used a $3 \times 3$ pixel group as a guarantee of high quality metric (QA). Land surface reflectance values were average for the nine pixels partially covering the eddy flux tower, and only the pixel with highest quality assurance metrics were used. However, varying sensor viewing geometry, cloud presence, aerosols and bidirectional reflectance can limit the efficacy of reflectance data for assessing spatial-temporal dynamics in biophysical processes (Hird and McDermid, 2009), and signal extraction techniques are often needed to improve the signal-noise ratio (Hermance et al., 2007). Thus, we applied Singular Spectrum Analysis (Zeilhofer et al., 2011), using the CatMV software (Golyandina and Osipova, 2007), which is particularly effective for the filtered reconstruction of short, irregularly spaced, and noisy time series (Ghil et al., 2002; Golyandina and Osipova, 2007) to improve the signal-noise ratio of the MODIS land surface reflectance.

\subsection{MODIS 8-day gross primary production product}

The Gross Primary Production product (MOD17A2) is designed to provide regular measure of the growth of terrestrial vegetation based on the light-use efficiency (LUE) concept using daily MODIS land cover, FPAR/LAI and surface meteorology at $1 \mathrm{~km}$ for the global vegetated land surface (Turner et al., 2006). The product is calculated using the equation:

$$
G P P=\varepsilon_{\max } \cdot m\left(T_{\min }\right) \cdot m(V P D) \cdot F P A R . S W r a d .0 .45
$$

where $\varepsilon_{\max }$ is the maximum LUE obtained from lookup table on the basis of vegetation type, $m\left(T_{\text {mim }}\right)$ and $m(V P D)$ are the scalers to reduce $\varepsilon_{\max }$ under unfavorable conditions of low temperature and high vapor pressure deficit (VPD), FPAR is the Fraction of
Photosynthetically Active Radiation absorbed by the vegetation and $S W_{\text {rad }}$ is shortwave radiation. As the MOD09A1, we used a 3x3 pixel group of MOD17A2 as a guarantee of high quality metric (QA).

\subsection{Vegetation index}

Land surface reflectance values from blue $\left(\rho_{\text {blue }}\right)$, red $\left(\rho_{\text {red }}\right)$, near-infrared $\left(\rho_{\text {nir }}\right)$ and short wave infrared $\left(\rho_{\text {swir }}\right)$ were used to calculate the Enhanced Vegetation Index (EVI, Huete et al., 1997) and the Land Surface Water Index (LSWI) (Xiao et al., 2004a). The LSWI was proposed by Xiao et al. (2002). EVI has been used for characterizing the seasonal variation of temperate forest (Xiao et al., 2004a,b) and tropical forest (Xiao et al., 2005; Vourlitis et al., 2011). EVI (Equation 3) includes the blue band for atmospheric correction, and it works well in accounting for residual atmospheric contamination (e.g. aerosols), variable soil, and canopy background reflectance (Huete et al., 1997). EVI directly normalizes the reflectance in red band as a function of the reflectance in blue band.

$$
E V I=2.5 \frac{\rho_{\text {nir }}-\rho_{\text {red }}}{\rho_{\text {nir }}+6 \rho_{\text {blue }}-7.5 \rho_{\text {red }}+1}
$$

As the short infrared (SWIR) spectral band is sensitive to vegetation water content and soil moisture, a combination of NIR (band 2) and SWIR (band 6) have been used to derive water sensitive vegetation indices (Equation 4). The SWIR absorption increases and SWIR reflectance decreases as the leaf liquid water content increases or soil moisture increases, resulting in an increase of LSWI.

$$
L S W I=\frac{\rho_{\text {nir }}-\rho_{\text {swir }}}{\rho_{\text {nir }}+\rho_{\text {swir }}}
$$

\subsection{Vegetation photosynthesis model (VPM)}

The $\mathrm{GPP}_{\mathrm{VPM}}$ estimated by the VPM model (Equation 5 ) is a function of incident photosynthetically active radiation

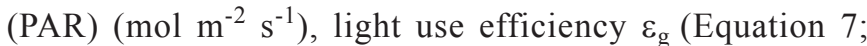
$\mathrm{gC}$ molPAR ${ }^{-1}$ ) and fraction of absorbed PAR by chlorophyll (FPAR) in the vegetation canopy (Vetrita et al., 2011):

$$
G P P=\varepsilon_{g} . F P A R . P A R
$$

In this study FPAR (Equation 6) was assumed to be a linear function of EVI (Equation 3), and the coefficient $\alpha$ was simply set to be 1.0 (Xiao et al., 2004a,b; Xiao et al., 2005; Wang et al., 2010).

$$
F P A R=\alpha . E V I
$$

The $\varepsilon_{g}$ (Equation 6) is a challenging variable to be determined at a global scale (Wu et al., 2010) because it is often measurable meteorological variables representing canopy 
stresses, such as temperature and water content (Running et al., 2004).

$$
\varepsilon_{g}=\varepsilon_{o} \cdot T_{e s c} \cdot W_{e s c} \cdot P_{e s c}
$$

where $\varepsilon_{0}$ is the maximum light use efficiency $\left(\mathrm{gC}\right.$ molPAR $\left.{ }^{-1}\right)$ and $T_{\text {esc }}, W_{\text {esc }}$ and $P_{\text {esc }}$ are down-regulation scalars, ranging between 0 and 1, for the effects of temperature (Equation 8), water (Equation 9), and leaf phenology (Equation 10) on light use efficiency of vegetation, respectively:

$$
\begin{aligned}
& T_{e s c}=\frac{\left(T-T_{\min }\right)\left(T-T_{\max }\right)}{\left[\left(T-T_{\min }\right)\left(T-T_{\max }\right)\right]-\left(T-T_{\text {opt }}\right)^{2}} \\
& W_{\text {esc }}=\frac{1+L S W I}{1+L S W I_{\max }} \\
& P_{\text {esc }}=\frac{1+L S W I}{2}
\end{aligned}
$$

where $T$ is the air temperature at $40 \mathrm{~m}$ at each time step $\left({ }^{\circ} \mathrm{C}\right)$, and $T_{\min }, T_{\max }$ and $T_{\text {opt }}$ are the minimum, maximum and optimal air temperature for photosynthetic activities $\left({ }^{\circ} \mathrm{C}\right)$, respectively. If air temperature falls below $T_{\min }, T_{\text {scalar }}$ is set to zero. $L S W I_{\max }$ is the maximum $L S W I$ within the plant growing season for individual pixels.

Semi-deciduous trees in the tropical zone have a green canopy throughout the year because foliage is retained for several growing seasons. Canopies of semi-deciduous forests are thus composed of green leaves of various ages. In this study, a simple assumption of $P_{\text {scalar }}$ set to 1 , similar to the assumption used for evergreen broadleaf forest (Xiao et al., 2005).

\subsection{Analysis of the model parameters}

Some of the factors that control vegetation productivity are the amount of green biomass, chlorophyll concentration and some environmental parameters that may affect photosynthesis, e.g., light, air temperature and water availability in the system. To estimate the GPP by VPM model according to the MODIS data and local climate data, we estimated the $\varepsilon_{o}, T_{\min }, T_{\max }$ $T_{\text {opt }}$ and $L S W I_{\max }$.

\subsubsection{Estimation of maximum light use efficiency}

According to Pinheiro (1994), 55\% of solar energy is not used for photosynthesis due to light loss by reflection and transmission to the ground. The concept of light use efficiency (LUE) was proposed by Monteith (1972) and its application brought contributions to the concepts of the carbon sink processes by vegetation.

The value of light use efficiency need to be strictly calibrated, because it has great impact on the model, beyond it is a factor that varies according to each specific vegetation (Yang et al., 2007; Sims et al., 2008). The estimation of $\varepsilon_{0}$ is determined by the choice of the model, which can be linear or nonlinear (e.g., hyperbolic) (Xiao et al., 2004b). As proposed by the VPM model (Xiao et al., 2004a), we estimated the light use efficiency according to the Michaelis-Menten function:

$$
N E E=\frac{\varepsilon_{o} \cdot P A R \cdot G P P_{\max }}{\varepsilon_{o} \cdot P A R+G P P_{\max }}-R
$$

where $G P P_{\max }$ is the maximum gross primary production $(\mathrm{gC}$ $\mathrm{m}^{-2}$ day $\left.^{-1}\right)$.

The VPM model proposes a fixed value for $\varepsilon_{0}$ (Xiao et al., 2004a). However, we consider the GPP dynamics and monthly estimate of $\varepsilon_{0}$ due to the amount of data.

\subsubsection{Estimation of down-regulation scalars}

The photosynthetic activity of plants is most effective within a certain air temperature range, and above or below this range the chemical reactions necessary for photosynthesis are inhibited (Xiao et al., 2004b). This range is large and varies from vegetation to vegetation. We estimated the $T_{\min }$ as $2.0^{\circ} \mathrm{C}, T_{\max }$ as $48.0^{\circ} \mathrm{C}$ and $T_{o p t}$, as $28.0^{\circ} \mathrm{C}$, which is similar to the values found by Xiao et al. (2005) and Vetrita et al. (2011) for tropical forests.

To calculate $W_{e s c}$, it was necessary to estimate $L S W I$ during the study period (Equation 3). The estimated value $L S W I_{\max }$ was 0.38 , which is consistent with the value found by Vetrita et al. (2011) in tropical forests.

\section{RESULTS AND DISCUSSION}

\subsection{Seasonal and interannual analyses of estimated GPP by eddy covariance and meteorological data}

The GPP estimate by eddy covariance $\left(\mathrm{GPP}_{\mathrm{EC}}\right)$ did not differentiate one year following the other (Table 1), but the $\mathrm{GPP}_{\mathrm{EC}}$ during 2007-2008 was 16\% higher than during 20052006, showing an increasing trend during the three years. The $\mathrm{GPP}_{\mathrm{EC}}$ had a seasonal cycle, and it was on average $28 \%$ higher in the wet season (Table 1). In the three years analyzed, the $\mathrm{GPP}_{\mathrm{EC}}$ had similar dynamic, increasing gradually from July to November, whose peak was in November during 2005-2006, in January during 2006-2007, and 2007-2008 (Figure 2a).

The difference in annual and monthly $\mathrm{GPP}_{\mathrm{EC}}$ mean can be explained by the dynamics of precipitation (Figure 2b), temperature and photosynthetically active radiation (PAR) (Figure 3). The $\mathrm{GPP}_{\mathrm{EC}}$ had strongly correlated with rainfall ( $\mathrm{r}$ $=0.64)$, and well-defined peaks in the wet season. The total annual rainfall during 2005-2006 and 2007-2008 was lower (60$100 \mathrm{~mm}$ ) than the 30 years historical average of the study area 


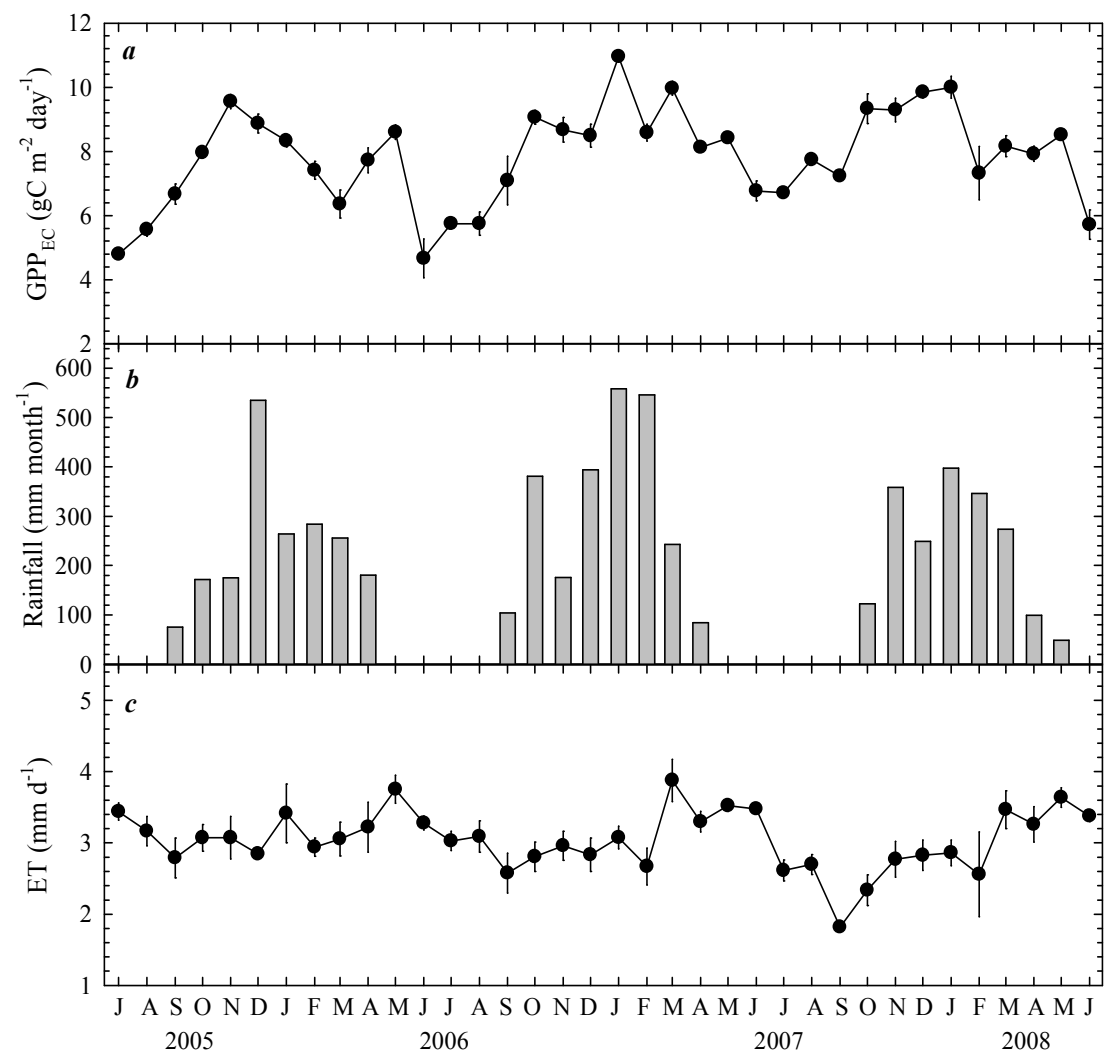

Figure 2 - (a) Average $( \pm \mathrm{sd})$ monthly gross primary production estimated by eddy covariance (GPPEC), (b) total monthly precipitation and (c) Average ( \pm sd) monthly evapotranspiration between July 2005 and June 2008.

Table 1 - Average ( \pm Standard Deviation) air temperature (Air Temp. $\left.-{ }^{\circ} \mathrm{C}\right)$, photosynthetically active radiation $\left(\mathrm{PAR}-\mu \mathrm{mol} \mathrm{m}{ }^{-2}\right.$ day $\left.{ }^{-1}\right)$, fraction of absorbed PAR (FPAR), Land Surface Water Index (LSWI), Enhanced Vegetation Index (EVI), down-regulation scalars for the effects of temperature (Tesc) and water (Wesc), maximum light use efficiency $\left(\varepsilon 0-\mathrm{gC}_{\mu} \mathrm{molPAR}^{-1}\right)$, light use efficiency $\left(\varepsilon \mathrm{g}-\mathrm{gC} \mu \mathrm{molPAR}^{-1}\right)$, Gross Primary Production estimated by eddy covariance method $\left(\mathrm{GPP}-\mathrm{gC} \mathrm{m}^{-2} \mathrm{day}^{-1}\right)$, Gross Primary Production predicted by VPM model $\left(\mathrm{GPPVPM}-\mathrm{gC} \mathrm{m}^{-2} \mathrm{day}^{-1}\right), \mathrm{Gross}$ Primary Production predicted by MODIS product (GPPMODIS $-\mathrm{gC} \mathrm{m}^{-2} \mathrm{day}^{-1}$ ) and precipitation (mm), calculated for annual, dry season, and wet season periods from 2005 to 2008.

\begin{tabular}{|c|c|c|c|c|c|c|c|c|c|}
\hline & \multicolumn{3}{|c|}{ Annual } & \multicolumn{3}{|c|}{ Dry } & \multicolumn{3}{|c|}{ Wet } \\
\hline & 2005-06 & 2006-07 & 2007-08 & 2005-06 & 2006-07 & 2007-08 & 2005-06 & 2006-07 & 2007-08 \\
\hline Air Temp. & $25.18 \pm 1.33$ & $24.62 \pm 0.80$ & $24.34 \pm 0.68$ & $25.01 \pm 1.52$ & $24.31 \pm 0.83$ & $24.24 \pm 0.69$ & $25.32 \pm 1.22$ & $24.84 \pm 0.73$ & $24.39 \pm 0.70$ \\
\hline PAR & $432.30 \pm 94.82$ & $418.77 \pm 84.51$ & $379.84 \pm 84.27$ & $478.96 \pm 51.04$ & $477.02 \pm 64.61$ & $445.15 \pm 80.30$ & $394.96 \pm 107.11$ & $377.16 \pm 72.62$ & $340.66 \pm 60.86$ \\
\hline FPAR & $0.894 \pm 0.008$ & $0.886 \pm 0.020$ & $0.883 \pm 0.023$ & $0.893 \pm 0.007$ & $0.892 \pm 0.009$ & $0.889 \pm 0.011$ & $0.894 \pm 0.009$ & $0.881 \pm 0.025$ & $0.880 \pm 0.028$ \\
\hline LSWI & $0.335 \pm 0.019$ & $0.335 \pm 0.019$ & $0.333 \pm 0.018$ & $0.350 \pm 0.010$ & $0.351 \pm 0.011$ & $0.350 \pm 0.013$ & $0.323 \pm 0.016$ & $0.324 \pm 0.016$ & $0.324 \pm 0.014$ \\
\hline EVI & $0.59 \pm 0,01$ & $0.58 \pm 0,01$ & $0.59 \pm 0,01$ & $0.58 \pm 0,02$ & $0.56 \pm 0,02$ & $0.57 \pm 0,02$ & $0.60 \pm 0,01$ & $0.60 \pm 0,01$ & $0.60 \pm 0,01$ \\
\hline $\mathbf{T}_{\text {esc }}$ & $0.987 \pm 0.016$ & $0.994 \pm 0.007$ & $0.995 \pm 0.003$ & $0.988 \pm 0.016$ & $0.995 \pm 0.004$ & $0.996 \pm 0.003$ & $0.986 \pm 0.017$ & $0.993 \pm 0.009$ & $0.995 \pm 0.002$ \\
\hline $\mathbf{W}_{\text {esc }}$ & $0.967 \pm 0.013$ & $0.967 \pm 0.014$ & $0.966 \pm 0.013$ & $0.978 \pm 0.007$ & $0.979 \pm 0.008$ & $0.978 \pm 0.009$ & $0.959 \pm 0.011$ & $0.959 \pm 0.012$ & $0.959 \pm 0.010$ \\
\hline$\varepsilon_{0}$ & $0.028 \pm 0.014$ & $0.0322 \pm 0.013$ & $0.043 \pm 0.018$ & $0.018 \pm 0.007$ & $0.022 \pm 0.007$ & $0.033 \pm 0.024$ & $0.036 \pm 0.013$ & $0.039 \pm 0.011$ & $0.049 \pm 0.012$ \\
\hline$\varepsilon_{\mathrm{g}}$ & $0.017 \pm 0.008$ & $0.020 \pm 0.008$ & $0.027 \pm 0.011$ & $0.012 \pm 0.004$ & $0.014 \pm 0.0047$ & $0.022 \pm 0.015$ & $0.022 \pm 0.008$ & $0.025 \pm 0.006$ & $0.031 \pm 0.008$ \\
\hline $\mathbf{G P P}_{\mathrm{EC}}$ & $7.32 \pm 1.49$ & $7.97 \pm 1.45$ & $8.87 \pm 1.46$ & $6.18 \pm 1.29$ & $6.93 \pm 1.18$ & $7.98 \pm 1.62$ & $8.24 \pm 0.92$ & $8.72 \pm 1.16$ & $9.40 \pm 1.12$ \\
\hline $\mathbf{G P P}_{\mathrm{VPM}}$ & $6.30 \pm 1.74$ & $7.13 \pm 1.86$ & $8.37 \pm 2.14$ & $5.05 \pm 1.45$ & $5.94 \pm 1.36$ & $7.36 \pm 2.44$ & $7.30 \pm 1.27$ & $7.97 \pm 1.72$ & $8.97 \pm 1.79$ \\
\hline GPP $_{\text {MODIS }}$ & $4.76 \pm 1.47$ & $5.30 \pm 1.40$ & $5.65 \pm 1.30$ & $4.15 \pm 1.87$ & $4.74 \pm 1.82$ & $5.19 \pm 1.53$ & $5.26 \pm 0.86$ & $5.67 \pm 0.96$ & $5.86 \pm 1.21$ \\
\hline Ppt & 1498.5 & 2100.6 & 1663.1 & 89.5 & 104 & 49 & 1409 & 2048.6 & 1638.6 \\
\hline
\end{tabular}


Table 2 - Matrix of Pearson correlation of air temperature, photosynthetically active radiation (PAR), fraction of absorbed PAR (FPAR), Land Surface Water Index (LSWI), Enhanced Vegetation Index (EVI), maximum light use efficiency (Eo), Gross Primary Production estimated by eddy covariance method (GPPEC), Gross Primary Production estimated by VPM model (GPPVPM), Gross Primary Production estimated by MODIS product (GPPMODIS) and precipitation.

\begin{tabular}{|c|c|c|c|c|c|c|c|c|c|}
\hline & Air Temp. & PAR & FPAR & LSWI & EVI & $\varepsilon_{0}$ & GPP & $\mathbf{G P P}_{\mathrm{VPM}}$ & GPP $_{\text {MODIS }}$ \\
\hline PAR & 0.025 & 1 & & & & & & & \\
\hline FPAR & 0.016 & 0.105 & 1 & & & & & & \\
\hline LSWI & 0.004 & $0.667 * *$ & -0.103 & 1 & & & & & \\
\hline EVI & $0.471 *$ & -0.128 & -0.164 & 0.054 & 1 & & & & \\
\hline$\varepsilon_{0}$ & -0.091 & $-0.785^{* *}$ & -0.159 & $-0.499 * *$ & 0.112 & 1 & & & \\
\hline $\mathbf{G P P}_{\mathrm{EC}}$ & -0.052 & $-0.468^{* *}$ & -0.235 & $-0.389^{*}$ & 0.253 & $0.828 * *$ & 1 & & \\
\hline $\mathbf{G P P}_{\mathrm{VPM}}$ & -0.129 & $-0.420^{*}$ & -0.176 & -0.323 & 0.203 & $0.831 * *$ & $0.984 * *$ & 1 & \\
\hline GPP $_{\text {MODIS }}$ & $-0.455^{* *}$ & $-0.376^{*}$ & 0.075 & $-0.636^{* *}$ & $-0.407 *$ & $0.430^{*}$ & $0.439^{*}$ & $0.429 *$ & 1 \\
\hline Ppt & 0.062 & $-0.626^{* *}$ & -0.108 & $-0.524 * *$ & $0.472 *$ & $0.575 * *$ & $0.498^{* *}$ & $0.446^{* *}$ & 0.190 \\
\hline
\end{tabular}

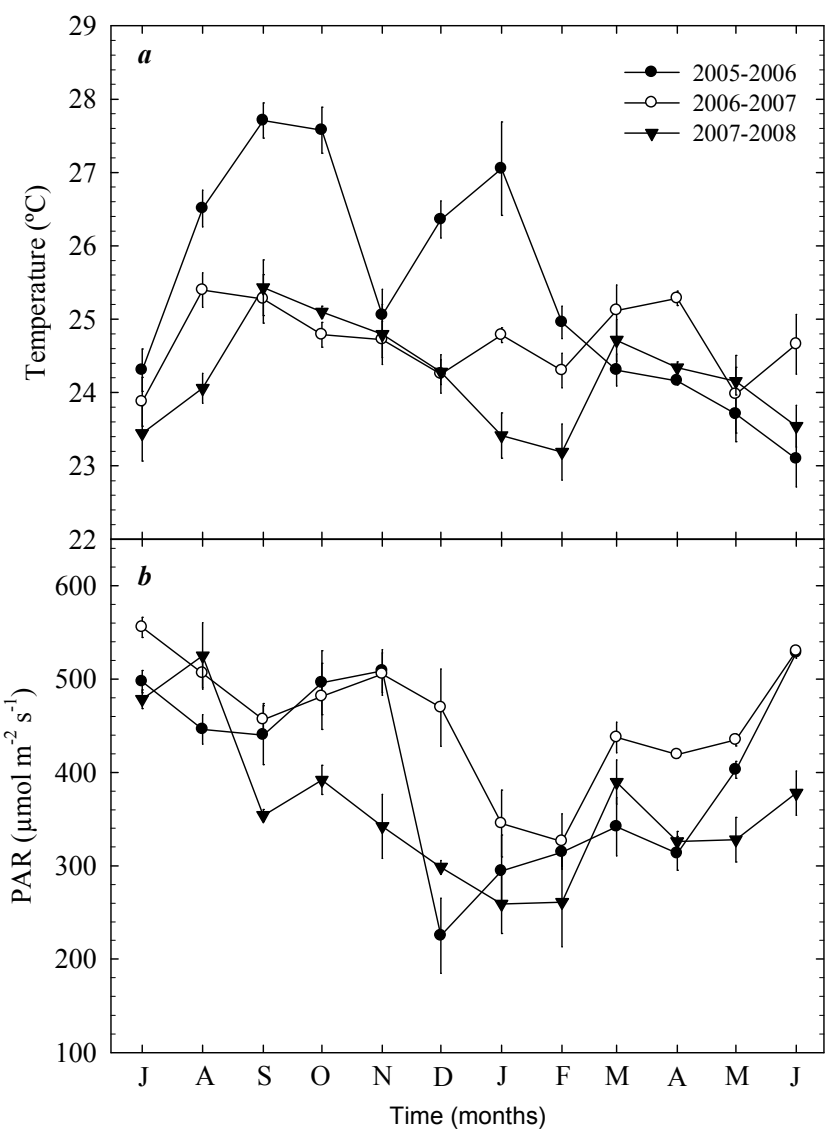

Figure 3 - (a) Average $( \pm$ sd) monthly air temperature and (b) photosyntheticaly active radiation for 2005-2006 (solid circles), 20062007 (open circles) and 2007-2008 (solid triangles).

(Vourlitis et al., 2002), while during 2006-2007 the precipitation was approximately $500 \mathrm{~mm}$ higher than the historical average (Figure 2b). The greatest total annual rainfall during 20062007 was due to peaks occurred during October, January and February, during the wet season occurred on average $96 \%$ of the total rainfall (Table 1), and between June and August there was no precipitation. The air temperature was higher during 2005-2006, no difference during 2006-2007, and during 2005-
2006 was lower than 2007-2008 (Table 1 and Figure 3a). The air temperature had not seasonality, so there was no correlation between air temperature and $\mathrm{GPP}_{\mathrm{EC}}$. However, we observed the highest average air temperature in the wet season of 2005-2006 (Figure 3a). The photosynthetically active radiation (PAR) was negatively correlated with GPP $(r=-0.39)$ (Table 2$)$, because the greater number of days of clear skies, which increased PAR values during June and July of the dry season (Table 1 and Figure $3 b$ ).

Evapotranspiration (ET) was consistent over the three years of study, no seasonal variation and interannual, which influenced the lack of correlation between ET and GPP (Table 1 and Figure 2c). The temporal consistency of ET can be explained by root access to deep water reserves. Vourlitis et al. (2008) reported that ET and sap flow of the Amazon-Cerrado transitional forest are supplied by groundwater during the dry season. Due to access to water by plants, high values of vapor pressure deficit and solar radiation during the dry season leading to high rates of ET.

Thus, the lowest values of $\mathrm{GPP}_{\mathrm{EC}}$ during 2005-2006, intermediate during 2006-2007 and higher during 2007-2008 were not due to soil water stress caused by water scarcity. Probably, the annual variation of $\mathrm{GPP}_{\mathrm{EC}}$ occurred by the dynamic of meteorological conditions during the study period in the Amazon-Cerrado transitional forest: dry and hot during 2005-2006, humid and hot during 2006-2007, and dry and cold during 2007-2008 (Vourlitis et al., 2011). The dry season of 2005 has particular interest due to a severe drought reported in the south of the Amazon basin (Marengo et al., 2008). The occurrences of seasonal and interannual droughts are potentially important in controlling the productivity of tropical ecosystems (Vourlitis et al., 2005; Vourlitis and da Rocha, 2010).

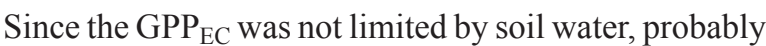
the canopy phenology, represented by the maximum light use efficiency $\left(\varepsilon_{0}\right)$ has influenced the dynamics of GPP $\mathrm{EC}$. The $\varepsilon_{0}$ increased over the three years analyzed and $\varepsilon_{0}$ was 2 -fold higher in the wet season than in dry season (Table 1 ; Figure 4). The $\varepsilon_{0}$ showed the same causes of variation in the estimated $\mathrm{GPP}_{\mathrm{EC}}$, however, with higher values of correlation coefficients (Table 


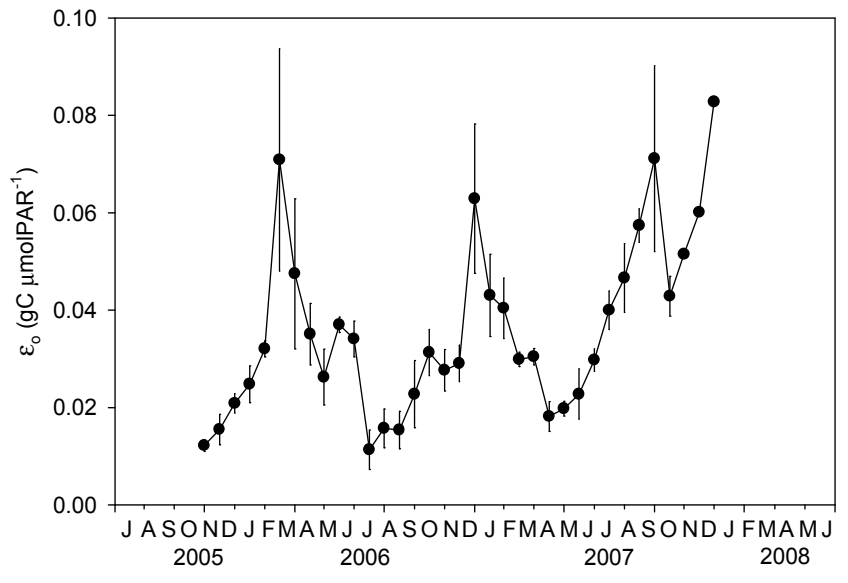

Figure 4 - Average $( \pm$ Sd $)$ monthly maximum light use efficiency $(\varepsilon 0)$ of the Amazon-Cerrado transitional forest from July 2005 to June 2008.

2). The $\varepsilon_{0}$ was positively correlated with precipitation $(\mathrm{r}=0.77)$, not correlated with air temperature and was negatively correlated with PAR $(r=-0.77)$. In tropical forests, rates of photosynthesis and respiration of the ecosystem are strongly correlated with rainfall due to its high seasonal variability (Vourlitis et al., 2011; Samanta et al., 2010). The importance of precipitation for the light use efficiency has been well documented and observed by Sendall et al. (2009) and Vourlitis et al. (2011) to study the photosynthesis rates and $\mathrm{CO}_{2}$ net ecosystem exchange (NEE) in the same area of this study. The negative relationship between PAR and $\varepsilon_{0}$ is not conclusive, because there is little evidence that the light use efficiency is affected by the amount of radiation (Boardman, 1977).

\subsection{Variation of orbital data}

The mean EVI and LSWI were not different between years (Table 1), but there were seasonal dynamics of them. The EVI was on average 5\% higher in the wet season, increasing from June to November, with maximum in December (Figure 5a). The LSWI had a distinct seasonal dynamics, with on average $8 \%$ higher during the dry season, increasing from April to August, with maximum in August (Figure 5b). The differences in the EVI and LSWI dynamics were due to a time lag of two months between these indices, which influenced the weak correlation between EVI and $\operatorname{GPP}_{\mathrm{EC}}(\mathrm{r}=0.44)$ and between LSWI and GPP $\mathrm{EC}(\mathrm{r}=-0.30)$.

The positive relationship of $\mathrm{GPP}_{\mathrm{EC}}$ and EVI of tropical forests is well documented and expected, since the EVI dynamic is related to the forest canopy cover dynamics (Xiao et al., 2005). Thus, the spectral reflectance is positively correlated with LAI, concentration of photosynthetic pigments and nutrients in the leaf (Asner and Martin, 2008). The EVI was positively correlated with precipitation $(\mathrm{r}=$
0.47) (Table 2). There is an increase in leaf area index (LAI) and consequently photosynthesis in the wet season (Vourlitis et al., 2005, 2011).

The LSWI has been used to characterize water conditions of the vegetation in this study, its highest values occur when the ecosystem water availability increases (Xiao et al., 2004a; Xiao et al., 2005). However, the LSWI was negatively correlated with precipitation $(\mathrm{r}=-0.48)$ (Table 2). During the study period, the highest value of LSWI occurred in the month prior to the occurrence of precipitation (in August) and the lowest value LSWI occurred in the last month of occurrence of precipitation (April). The soil water content is lower during the dry season than in wet season (Saleska et al., 2003; Vourlitis et al., 2011). However, ET is slightly higher during the dry season than during wet season (Figure 2c). Due to the Amazon-Cerrado transitional forest canopy be closed, the values of reflectance measured by orbital sensors are not directly influenced by soil water content, but by leaves water content. The high values of LSWI during the dry season can be attributed to: (1) high proportion of young leaves (higher leaf water content) as indicated by the seasonal dynamics of

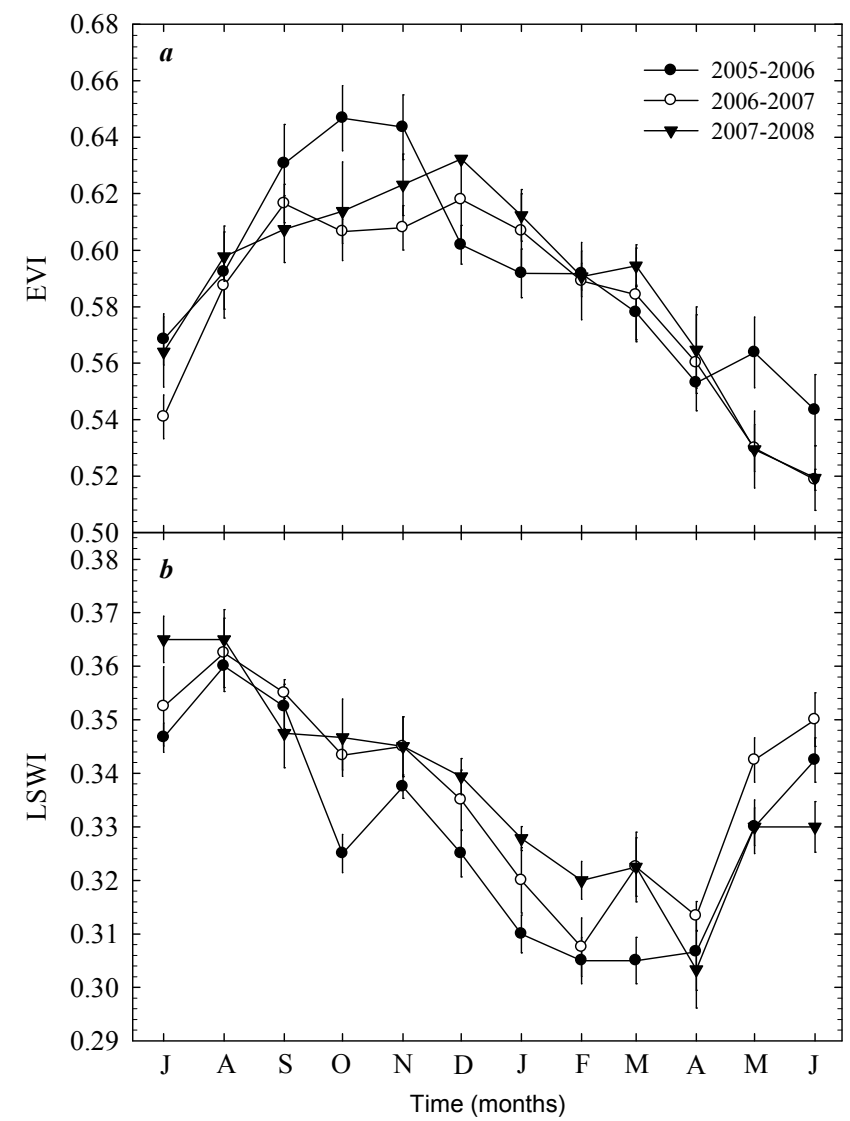

Figure 5 - (a) Average ( \pm sd) monthly enhanced vegetation index (EVI) and (b) land surface water index (LSWI) for 2005-2006 (solid circles), 2006-2007 (open circles) and 2007-2008 (solid triangles). 
EVI, and (2) high water-equivalent thickness the upper canopy supplied by the deep root system. Young leaves have higher water content than the older leaves (Roberts et al., 1998). Thus, the seasonal dynamic of LSWI indicates no water stress along the dry season in the evaluated years.

\subsection{GPP Estimated by VPM and MODIS product}

The seasonal dynamics of predicted GPP of AmazonCerrado transitional forest by VPM using MODIS data and microclimate data $\left(\mathrm{GPP}_{\mathrm{VPM}}\right)$ and GPP by GPP MODIS product $\left(\mathrm{GPP}_{\text {MODIS }}\right)$ agreed with GPP estimated by eddy covariance $\left(\mathrm{GPP}_{\mathrm{EC}}\right)$ on both, phase and magnitude, according MANOVA test (Figure 6). The annual GPP $\mathrm{EC}_{\text {was }} 26.9$ ton $\mathrm{ha}^{-1}, 30.3$ ton $\mathrm{ha}^{-1}$ and 31.2 ton $\mathrm{ha}^{-1}$, the annual GPP $\mathrm{VPM}$ was 24.2 ton ha ${ }^{-1}$, 28.8 ton $\mathrm{ha}^{-1}$ and 31.0 ton $\mathrm{ha}^{-1}$ and the annual GPP $\mathrm{MODIS}$ was 17.4 ton ha ${ }^{-1}, 19.3$ ton $\mathrm{ha}^{-1}$ and 20.6 ton ha-1 during 20052006, 2006-2007 and 2007-2008, respectively. In general, the $\mathrm{GPP}_{\mathrm{VPM}}$ was underestimated $8.0 \%$ on average, due $21.4 \%$ of underestimation in the dry season and $3.5 \%$ of overestimation in the wet season; and the GPP $\mathrm{GODIS}_{\text {Mas }}$ underestimated $38.0 \%$ on average, due the underestimation of $33.2 \%$ and $36.3 \%$ in the dry and wet seasons, respectively (Table 1). Linear regression showed high correlation between the $\mathrm{GPP}_{\mathrm{EC}}$ and $\mathrm{GPP}_{\mathrm{VPM}}(\mathrm{r}=$ 0.93 ), with a MAE of $0.43 \mathrm{gC} \mathrm{m}^{-2}$ day $^{-1}$, RMSE of $0.87 \mathrm{gC} \mathrm{m}^{-2}$ day $^{-1}$. However, the GPP $\mathrm{MODIS}_{\mathrm{S}}$ had low correlation with $\mathrm{GPP}_{\mathrm{EC}}$ $(\mathrm{r}=0.43)$, with a MAE of $1.95 \mathrm{gC} \mathrm{m}^{-2} \mathrm{day}^{-1}$, RMSE of $4.35 \mathrm{gC}$ $\mathrm{m}^{-2}$ day $^{-1}$ (Figure 7).

Since the $T_{\text {scalar }}$ and $W_{\text {scalar }}$ presented practically no variation between the years and seasons (Table 1), the underestimation of $\mathrm{GPP}_{\mathrm{VPM}}$ in the dry season may be due to

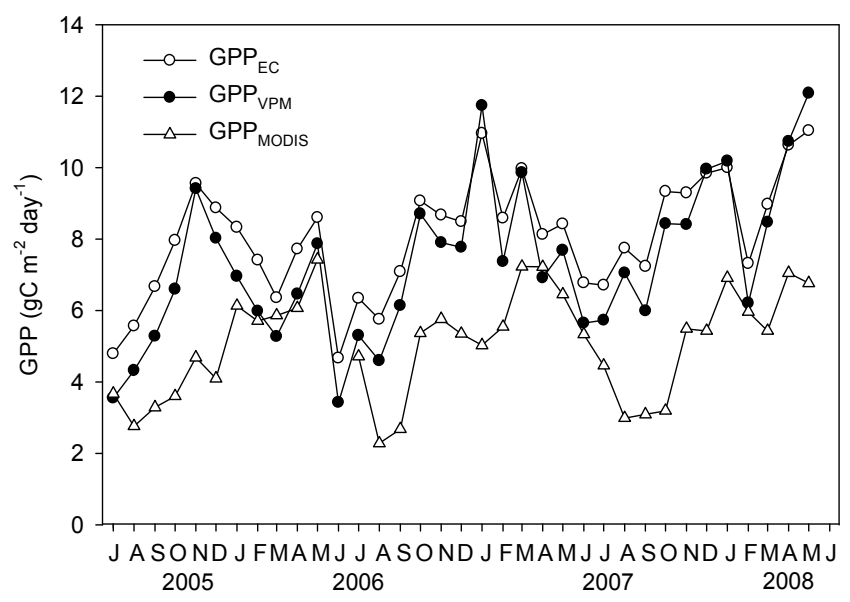

Figure 6 - Average monthly GPP estimated by eddy covariance method (GPPEC) and predicted by vegetation photosynthesis model (GPPVPM) and MODIS product (GPPMODIS) in the Amazon-Cerrado transitional forest from July 2005 to June 2008. lower EVI values between May and July. As the dynamics of EVI reflects the phenology of plants, this enhances that the phenology of plants has an important influence on GPP. Some found errors could be attributed to climate input data and vegetation indices. This result corroborates the estimated GPP in Amazon forests (Xiao et al., 2005).

The low capacity of MODIS product to predict GPP is due to the improper of characterizing of LUE of the Amazon-Cerrado transitional forest of this study. The MOD17A2 uses lookup tables of maximum LUE determination for a given vegetation type and the adjustment of LUE values can be downward on the basis of environmental stress factor (Sims et al., 2006). The typical difference between VPM and GPP MODIS product is the calculation of LUE, although both models use climate variables to reduce the maximum LUE under unfavorable condition ( Wu et al., 2010). The VPM use local climate variables whereas MOD17A2 uses produced data derived by a global circulation model (GCM), with incorporates both ground and satellite-based observation (Schubert et al., 1993).

\section{CONCLUSIONS}

$\mathrm{GPP}_{\mathrm{VPM}}$ and $\mathrm{GPP}_{\mathrm{MODIS}}$ showed similar dynamics with higher values in wet season and lower in dry season. Both methods have advantage and limitation to predict GPP. The $\mathrm{GPP}_{\mathrm{VPM}}$ showed better adjustment with $\mathrm{GPP}_{\mathrm{EC}}$, however VPM is limited by the local climate data input. The $\mathrm{GPP}_{\mathrm{MODIS}}$ had no good adjustment with $\mathrm{GPP}_{\mathrm{EC}}$, but the MOD17A2 can be used to predict GPP of a wide scale.

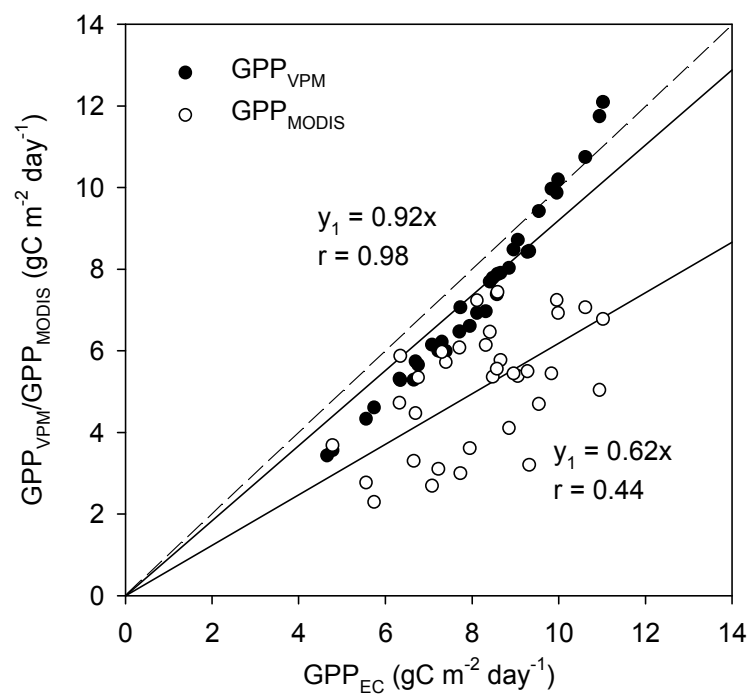

Figure 7 - Relationship of GPP predicted by vegetation photosynthesis model (GPPVPM) and MODIS product (GPPMODIS) with GPP estimated by eddy covariance (GPPEC) in the Amazon-Cerrado transitional forest. 
These results indicate the potential of VPM, which uses vegetation indices (EVI and LSWI) with meteorological data, and the MOD17A2 MODIS product to characterize the interannual and seasonal variation of GPP from an Amazon-Cerrado transitional forest. Moreover, it indicates the requirement of more study that uses the MOD17A2 in different tropical type of vegetation.

\section{ACKNOWLEDGMENTS}

This research was supported in part by the Coordenação de Aperfeiçoamento de Pessoal de Nível Superior - CAPES and by Fundação de Amparo à Pesquisa do Estado de Mato Grosso - FAPEMAT.

\section{REFERENCES}

AGUIAR, R. G.; RANDOW, C. V.; PRIANTE FILHO, N.; MANZI, A. O.; AGUIAR, L. J. G.; CARDOSO, F. L. Fluxos de massa e energia em uma floresta tropical no sudoeste da Amazônia. Revista Brasileira de Meteorologia, v.21, n.3b, p.248-257, 2006.

ASNER, G.P.; MARTIN, R.E. Spectral and chemical analysis of tropical forests: Scaling from leaf to canopy levels. Remote Sensing of Environment, v.112, p.3958-3970, 2008.

AUBINET, M.; VESALA, T.; PAPALE, D. (Eds.). A Practical Guide to Measurement and Data Analysis. Springer, Germany, 438 pp, 2012.

BALDOCCHI, D. Assessing the eddy covariance technique for evaluating carbon dioxide exchange rates of ecosystems: past, present and future. Global Change Biology, v.9, p.479-492, 2003.

BERNOUX, M.; CARVALHO, M.S.; VOLKOFF, B.; CERRI, C.C. Brazil's soil carbon stocks. Soil Science Society of America Journal, v.66, n.3, p.888-896, 2002.

BOARDMAN, N.K. Comparitive photosynthesis of sun and shade plants. Annual Review of Plant Physiology, v.28, p.355-377, 1977.

DALMAGRO, J.H.; ALMEIDA LOBO, F.; ORTÍZ, C.E.R.; BIUDES, M.S.; NOGUEIRA, J.S.; VOURLITIS, G.L.; PINTO JUNIOR, O.B. Trocas gasosas de uma espécie Lenhosa na floresta de transição amazônia - cerrado. Ciência e Natura, v.33, n.2, 147-165, 2011.

GHIL, M.; ALLEN, M.R.; DETTINGER, M.D.; IDE, K.; KONDRASHOV, D.; MANN, M.E.; ROBERTSON, A.W.; SAUNDERS, A.; TIAN, Y.; VARADI, F.; YIOU P. Advanced spectral methods for climatic time series. Reviews of Geophysics, v.40, n.1, 2002.

GOLYANDINA, N.; OSIPOVA, E. The "Caterpillar"-SSA method for analysis of time series with missing values.
Journal of Statistical Planning and Inference, v.137, p.2642-2653, 2007.

GRACE, J.; MALHI, Y.; LLOYD, J.; MCINTYRE, J.; MIRANDA, A.C.; MEIR, P.; MIRANDA, H.S. The use of eddy covariance to infer the net carbon dioxide uptake of Brazilian rain forest. Global Change Biology, v.2, p.209217, 1996.

HERRNANCE, J.F.; JACOB, R.W.; BRADLEY, B.A.; MUSTARD, J.F. Extracting phenological signals from multiyear A VHRR NDVI time series: Framework for applying high-order annual splines. IEEE Transactions on Geoscience and Remote Sensing, v.45, n.10, 2007.

HIRD, J.N.; MCDERRNID, G.J. Noise reduction of NDVI time series: An empirical comparison of selected techniques. Remote Sensing of Environment, v.113, p.248-258, 2009. HUETE, A.R.; DIDAN, K.; SHIMABUKURO, Y.E.; RATANA, P.; SALESKA, S.R.; HUTYRA, L.R.; YANG, W.Z.; NEMANI, R.R.; MYNENI, R. Amazon rainforests green-up with sunlight in dry season. Geophysical Research Letters, v.33, p.L06045, 2006.

HUETE, A.R.; LIU, H.Q.; BATCHILY, K.; VANLEEUWEN, W. A comparison of vegetation indices global set of TM images for EOSMODIS. Remote Sensing of Environment, v.59, p.440-451, 1997.

HUTYRA, L.R.; MUNGER, J.W.; SALESKA, S.R.; GOTTLIEB, E.; DAUBE, B.C.; DUNN, A.L.; AMARAL, D.F.; DE CAMARGO, P.B.; WOFSY, S.C. Seasonal controls on the exchange of carbon and water in an Amazonian rain forest. Journal of Geophysical Research-Biogeosciences, v.112, p.G03008, 2007.

KELLER, M.; ALENCAR, A.; ASNER, G.P.; BRASWELL, B.; BUSTAMANTE, M.; DAVIDSON, E.; FELDPAUSCH, T.; FERNANDES, E.; GOULDEN, M.; KABAT, P.; KRUIJT, B.; LUIZÃO, F.; MILLER, S.; MARKEWITZ, D.; NOBRE, A.D.; NOBRE, C.A.; PRIANTE FILHO, N.; DA ROCHA, H.; DIAS, P.S.; RANDOW, C.V.; VOURLITIS, G.L. Ecological research in the large-scale biosphere-atmosphere experiment in amazonia: early results. Ecological Applications, v.14, p.3-16, 2004.

KOTTEK, M.; GRIESER, J.; BECK, C.; RUDOLF, B.; RUBIEL, F. World map of the Köppen-Geiser climate classification updated. Meteorologishe Zeitschrift, v.15, n.3, p.259-263, 2006.

LI, Z.; YU, G.; XIAO, X.; LI, Y.; ZHAO, X.; REN, C.; ZHANG, L.; FU, Y. Modeling gross primary production of alpine ecosystems in the Tibetan Plateau using MODIS images and climate data. Remote Sensing of Environment, v.107, p.510-519, 2007.

MARENGO, J.A.; NOBRE, C.A.; TOMASELLA, J.; OYAMA, M.D.; DE OLIVEIRA, G.S.; DE OLIVEIRA, 
R.; CAMARGO, H.; ALVES, L.M.; BROWN, I.F. The drought of Amazonia in 2005. Journal of Climate, v.21, n.3, p.495-516, 2008.

MONTEITH, J.L. Solar radiation and productivity in tropical ecosystems. Journal of Applied Ecology, v.9, p.747-766, 1972.

MYNENI, R.B. et al. Large seasonal swings in leaf area of Amazon rainforests. PNAS, v.104, p.4820-4823, 2007.

PINHEIRO, F.J.A. 1994. Anatomia foliar, desenvolvimento e interceptação da luz de cultivares de arroz (Oryza sativa L.). Dissertação de Mestrado. Goiânia, Universidade Federal de Goiás. 1994.

ROBERTS, D.A.; NELSON, B.W.; ADAMS, J.B.; PALMER, F. Spectral changes with leaf aging in Amazon caatinga. Trees - Structure and Function, v.12, p.315-325, 1998.

RUNNING, S.W.; NEMANI, R.R.; HEINSCH, F.A.; ZHAO, M.; REEVES, M.; HASHIMOTO, H. A continuous satellitederived measure of global terrestrial primary production. BioScience, v.54, p.547-560, 2004.

SALESKA, S.; DA ROCHA, H.; KRUIJT, B.; NOBRE, A. Ecosystem carbon fluxes and Amazonian forest metabolism, in Amazonia and Global Change, Geophysical Monograph Series 186, edited by M. KELLER ET AL., pp. 389-408, AGU, Washington, D.C., 2009.

SALESKA, S.R.; MILLER, S.D.; MATROSS, D.M.; GOULDEN, M.L.; WOFSY, S.C.; DA ROCHA, H.R.; DE CAMARGO, P.B.; CRILL, P.; DAUBE, B.C.; DE FREITAS, H.C.; HUTYRA, L.; KELLER, M.; KIRCHHOFF, V.; MENTON, M.; MUNGER, J.W.; PYLE, E.H.; RICE, A.H.; SILVA, H. Carbon in Amazon forests: Unexpected seasonal fluxes and disturbance-induced losses. Science, v.302, p.1554-1557, 2003.

SAMANTA, A.; GANGULY, S.; HASHIMOTO, H.; DEVADIGA, S.; VERMOTE, E.; KNYAZIKHIN, Y.; NEMANI, R.R.; MYNENI, R.B. Amazon forests did not green-up during the 2005 drought. Geophysical Research Letters, v.37, p.L05401, 2010.

SANCHES, L.; VALENTINI, C.M.A.; PINTO JUNIOR, O.B.; NOGUEIRA, J.S.; VOURLITIS, G.L.; BIUDES, M.S.; SILVA, C.J.; BAMBI, P.; ALMEIDA LOBO, F. Seasonal and interannual litter dynamics of a tropical semideciduous forest of the southern Amazon Basin, Brazil. Journal of Geophysical Research, v.113, n.113, p.1-9. 2008.

SANTOS, S. N. M.; COSTA, M. H. Simulações de fluxo de carbono em um ecossistema de floresta tropical. Revista Brasileira de Meteorologia, v.18, n.1, p.87-96, 2003.

SCHUBERT, S.D.; ROOD, R.B.; PFAENDTNER, J. An assimilated dataset for earth science applications. Bulletin of the American Meteorological Society, v.74, n.12, p.2331-2342, 1993.
SENDALL, M.M.; VOURLITIS, G.L.; LOBO, F.A. Seasonal variation in the maximum rate of leaf gas exchange of canopy and understory tree species in an Amazonian semideciduous forest. Brazilian Journal of Plant Physiology, v.21, p.65-74, 2009.

SILVA, B.B.; MACHADO, C.C.C.; OLIVEIRA, L.M.M.; MOURA, M.S.B. Determinação por sensoriamento remote da produtividade primária bruta do perímetro irrigado São Gonçalo-PB. Revista Brasileira de Meteorologia, v.28, n.1, p.57-63, 2013.

SIMS, D.A.; RAHMAN, A.F., CORDOVA, V.D.; EL-MASRI, B.Z.; BALDOCCHI, D.D.; FLANAGAN, L.B.; Goldstein, A.H.; Hollinger, D.Y.; Misson, L.; Monson, R.K.; Oechel, W.C.; Schmid, H.P.; Wofsy, S.C.; Xu, L. On the use of MODIS EVI to assess gross primary productivity of North American ecosystems. Journal of Geophysical Research, v.111, p.G04015, 2006.

SIMS, D.A.; RAHMAN, A.F.; CORDOVA, V.D.; EL-MASRI, B.Z.; BALDOCCHI, D.D.; BOLSTAD, P.V.; FLANAGAN, L.B.; GOLDSTEIN, A.H.; HOLLINGER, D.Y.; MISSON, L.; MONSON, R.K.; OECHEL, W.C.; SCHMID, S.P.; WOFSY, S.C.; XU, L. A new model of gross primary productivity for North American ecosystems based solely on the enhanced vegetation index and land surface temperature from MODIS. Remote Sensing of Environment, v.112, p.1633-1646, 2008.

STAGAKIS, S.; MARKOS, N.; LEVIZOU, E.; KYPARISSIS, A. Forest ecosystem dynamics using spot and modis satellite images. In: ENVISAT SYMPOSIUM 2007. Montreux, Switzerland. July, 2007.

TURNER, D.P.; RITTS, W.D.; MAOSHENG, Z.; KURC, S.A.; DUNN, A.L.; WOFSY, S.C.; SMALL, E.E.; RUNNING, S.W. Assessing interannual variation in MODIS-based estimates of gross primary production. IEEE Transactions on Geoscience and Remote Sensing, v.44, n.7, p.18991907, 2006.

VETRITA, Y.; CHAOYANG, W.; ZHENG, N.; HIRANO, T. Evaluation of light use efficiency model using modis in tropical peat swamp forest, Indonesia. In: Second cresos International Symposium on south east Asia environmental problems and satellite remote sensing, 2011, Indonesia, p.127-134. 2011.

VOURLITIS, G.L.; DA ROCHA, H.R. Flux dynamics in the Cerrado and Cerrado-Forest Transition of Brazil. In: HILL, M.J.; HANAN, N.P. (Eds.), Ecosystem Function in Global Savannas: Measurement and Modeling at Landscape to Global Scales, pp. 97-116, CRC Press, Boca Raton, Fla., 2010.

VOURLITIS, G.L.; NOGUEIRA, J.S.; LOBO, F.A.; SENDALL, K.M.; DE FARIA, J.L.B.; DIAS, C.A.A.; ANDRADE, 
N.L.R. Energy balance and canopy conductance of a tropical semi-deciduous forest of the southern Amazon Basin. Water Resources Research, v.44, p.W03412, 2008.

VOURLITIS, G.L.; LOBO, F.A.; ZEIHLOFER, P.; NOGUEIRA, J.S. Temporal patterns of net $\mathrm{CO} 2$ exchange for a tropical semi-deciduous forest of the southern Amazon Basin. Journal of Geophysical Research, v.116, p.G03029, 2011. VOURLITIS, G.L.; NOGUEIRA, J.S.; PRIANTE-FILHO, N.; HOEGER, W.; RAILER, F.; BIUDES, M.S.; ARRUDA, J.C.; CAPISTRANO, V.B.; DE FARIA, J.L.B.; LOBO, F.A. The sensitivity of diel $\mathrm{CO} 2$ and $\mathrm{H} 2 \mathrm{O}$ vapor exchange of a tropical transitional forest to seasonal variation in meteorology and water availability. Earth Interactions Journal, v.9, p.1-23, 2005.

VOURLITIS, G.L.; PRIANTE FILHO, N.; HAYASHI, M.M.S.; NOGUEIRA, J.S.; RAITER, F.; HOEGER, W.; CAMPELO JUNIOR, J.H. Effects of meteorological variations of the $\mathrm{CO} 2$ exchange of a Brazilian transitional tropical Forest. Ecological Applications, v.14, n.4, p.S89-S100, 2004.

VOURLITIS, G.L.; PRIANTE FILHO, N.; HAYASHI, M.M.S.; NOGUEIRA, J.S.; CASEIRO, F.T.; CAMPELO JUNIOR, J.H. Seasonal variations in the evapotranspiration of a transitional tropical forest of MatoGrosso, Brazil. Water Resources Research, v.38, p. 1094, 2002.

WANG, Z.; XIAO, X.; YAN, X. Modeling gross primary production of maize cropland and degraded grassland in northeastern China. Agricultural and Forest Meteorology, v.150, p.1160-1167, 2010.

WEBB, E.K.; PEARMAN, G.I.; LEUNING, R. Corrections of flux measurements for density effects due water vapor transfer. Quarterly Journal of the Royal Meteorological Society, v.106, n.447, p.85-100, 1980.

WOHLFAHRT, G.; ANFANG, C.; BAHN, M.; HASLWANTER, A.; NEWESELY, C.; SCHMITT, M.; DROSLER, M.; PFADENHAEUR, J.; CERNUSCA, A. Quantifying nighttime ecosystem respiration of a meadow using eddy covariance, chambers and modeling. Agricultural and Forest Meteorology, v.128, p.141-162, 2005.

WU, C.; MUNGER, J.W.; NIU, Z.; KUANG, D. Comparison of multiple models for estimating gross primary production using MODIS and eddy covariance data in Harvard Forest. Remote Sensing of Environment, v.114, p.2925-2939, 2010 .
XIAO, X.; ZHANG, Q.; BRASWELL, B.; URBANSKI, S.; BOLES, S.; WOFSY, S.; MOORE III, B.; OJIMA, D. Modeling gross primary production of temperate deciduous broadleaf forest using satellite images and climate data. Remote Sensing of Environment, v.91, n.2, p.256-270, 2004b.

XIAO, X.; ZHANG, Q.; HOLLINGER, D.; ABER, J.; MOORE III, B. Modeling seasonal dynamics of gross primary production of an evergreen needleleaf forest using MODIS images and climate data. Ecological Applications, v.15, n.3, p.954-969, 2004a.

XIAO, X.; ZHANG, Q.; SALESKA, S.; HUTYRA, L.; DE CAMARGO, P.; WOFSY, S.; FROLKING, S.; BOLES, S.; KELLER, M.; MOORE B. Satellite-based Modeling of Gross Primary Production in a Seasonally Moist Tropical Evergreen Forest. Remote Sensing of Environment, v.94, n.1, p.105-122, 2005.

XIAO, X.M.; BOLES, S.; LIU, J.Y.; ZHUANG, D.F.; LIU, M.L. Characterization of forest types in Northeastern China, using multitemporal SPOT-4 VEGETATION sensor data. Remote Sensing of Environment, v.82, p.335-348, 2002.

YANG, F.H.; ICHII, K.; WHITE, M.A.; HASHIMOTO, H.; MICHAELIS, A.R.; VOTAVA, P.; ZHU, A.X.; HUETE, A.; RUNNING, S.W.; NEMANI, R.R. Developing a continental-scale measure of gross primary production by combining MODIS and AmeriFlux data through Support Vector Machine approach. Remote Sensing of Environment, v.110, p.109-122, 2007.

ZEILHOFER, P.; SANCHES, L.; VOURLITIS, G.L.; ANDRADE, N.L.R. Seasonal variations in litter production and its relation with MODIS vegetation indices in a semideciduous forest of Mato Grosso. Remote Sensing Letters, v.3, n.1, 2011.

ZHAO, M.; RUNNING, S.W. Drought-induced reduction in global terrestrial net primary production from 2000 through 2009. Science, v.329, p.940-943, 2010. 